якісне виконання індивідуальних завдань, а також формування готовності прикордонника до виконання службових завдань. У подальшому планується дослідити ефективні методи та педагогічні прийоми організації самостійної підготовки, а також проаналізувати чинники, які впливають на діяльність слухачів під час годин самостійної підготовки.

\title{
Література
}

1. Застосування Європейської кредитно-трансферної системи у навчальному процесу [Електронний ресурс]. - Режим доступу: http:/ / www. nbuv. gov. Ua / portal / soc_gum / pspo /2011_33_1/ Kucheryavuy. pdf

2. Кучерявий А. О. Суб’єктно-діяльнісні особливості процесу організації самостійної навчальної діяльності в юридичних навчальних закладах / А. О.Кучерявий // Проблеми сучасної педагогічної освіти: педагогіка і психологія: [зб. наук. праць]. - № 33. - 2011. - Режим доступу: http:// www. nbuv. gov. Ua / portal / soc_gum / pspo /2011_33_1 / Kucheryavuy. pdf

3. Наказ Голови ДПСУ «Про організацію мовної підготовки персоналу Державної прикордонної служби України до проведення в Україні Євро-2012» від 11. 02.2011 року № 90.

4. Наказ Адміністрації ДПСУ № 900 від 23. 11. 2011 року «Про підготовку персоналу Державної прикордонної служби у 2012 році».

5. Пидкасистый П. И. Организация учебно-познавательной деятельности студентов : [учеб. пособие] / П. И. Пидкасистый. - М. : Педаг. общ-во России, 2004. - 112c.

6. Псьол С. В. Дистанційне навчання в системі професійної підготовки прикордонників: досвід і перспективи розвитку / С. В. Псьол, Л. В. Цвяк [Електронний peсурс] // Збірник наукових праць. Серія: Психолого-педагогічні науки. - Хмельницький : Вид-во НАДПСУ. - № 56. - 2010. - Режим доступу: http: // www. nbuv. gov. Ua /portal / soc_gum / znpnapv_ppn / 2010_56 / 10 psvdpr.pdf

7. Солдатенко М.М. Теорія і практика самостійної пізнавальної діяльності : [монографія] / М. М. Солдатенко. - К. : Видавництво НПУ імені М. П. Драгоманова, 2006. - 198 с.

8. Трубачова С. Роль методів самостійного набуття знань в організації пізнавальної діяльності учнів / С. Трубачова // Рідна школа. - № 1. - 2001. - С. 39-41.

9. Яворська Г. Х. Соціально-професійна зрілість курсантів вищих навчальних закладів освіти МВС : [монографія] / Г. Х. Яворська. - Одеса : ПЛАСКЕ ЗАТ, 2005. - 408 с.

Стаття надійшла до редакції 15.05.2012 p.

\section{ПРОБЛЕМИ АДАПТАЦЇ̈ СТУДЕНТІВ-ПЕРШОКУРСНИКІВ ДО НАВЧАННЯ У ВНЗ}

Балахтар В. В. Проблеми адаптачії студентів-першокурсників до навчання у ВНЗ.

У статті досліджено проблему адаптації студентської молоді, охарактеризовано найбільш вагомі чинники, зокрема стан адаптованості студентів-першокурсників до умов навчання у ВНЗ.

Ключові слова: адаптаиія, студент-першокурсник, особистість, група, пристосування, взаємодія.

Балахтар В. В. Проблемы адаптачии студентов первокурсников к обучению в вузе.

В статье исследована проблема адаптации студенческой молодежи, охарактеризованы наиболее существенные показатели, в том числе уровень адаптации студентов-первокурсников в условиях обучения в вузе.

Ключевые слова: адаптация, студент-первокурсник, личность, группа, приспособление, взаимодействие. 
Balahtar V. Problems of freshmen students adapt to learning in higher education.

The article was concerned with the problem of student's adaptation and characterized the major factors. Has been investigated the state of adaptation of the first-year students to the learning environment in the school for higher education.

Key words: adaptation, first-year student, personality, group, device, interaction.

Актуальність теми дослідження. Проблема адаптації студентівпершокурсників до умов навчання у вищих навчальних закладах становить собою одне з важливих завдань, досліджуваних нині у педагогіці і дидактиці вищої школи. Процес адаптації студентів ВНЗ зумовлений специфікою застосування методів навчання в середній та вищій школі, а саме: адаптація студентів до навчальної діяльності обіймає вплив як суб'єктивних, так i об’єктивних чинників, до яких віднесено зміст та організація навчального процесу у ВНЗ. Студенту-першокурснику доводиться пристосовуватися до нових вимог, які висуває перед ним вища школа і водночас до нових соціальних обставин спілкування з однокласниками та педагогами, форм i методів навчання (самостійної роботи, групових форм взаємодії тощо) та побуту (відсутність звичного родинного кола, матеріальні труднощі, складність проживання в гуртожитку тощо).

Адаптація як соціальне явище становить процес включення особистості в нове для неї соціальне середовище, що потребує формування психологічних механізмів, завдяки яким особа забезпечить свою безпеку й адекватну орієнтацію в новій ситуації, швидко та успішно пристосується до нового соціального контексту життєдіяльності, окресленого межами єдиного професійного спрямування, специфічними вишівськими особливостями навчальної діяльності, що апелює, передовсім, до досить високого рівня розвитку особистості студента, його самостійності. Тобто, оволодіння високим рівнем самостійності є основою дидактичного процесу ВНЗ. Отже, проблема студентів першого курсу зумовлена їх адаптацією та самостійністю. За умови успішної адаптації особистість отримує можливість максимальної самореалізації без надмірних зусиль [6].

Стан дослідження проблеми. Проблемі адаптації студентів до умов навчання у ВНЗ у сучасній психологічній літературі приділено значну увагу. Зокрема, це наукові пошуки Т. Алексєєвої, Ю. Бохонкової, Н. Герасимової, В. Демченка, О. Кузнєцової，Л. Литвинової， В. Скрипник， І. Соколової та інших. Педагогічні аспекти адаптації студентів-першокурсників розглядаються в працях С. Гури, В.Матусевича, Т. Каткової, В. Сорочинської, В. Штифурак та інших. Науковці Д. Фельдштейн, І. Георгієва висвітлюють соціалізацію індивіда, адаптацію в мікрогрупі, колективі, суспільстві; залучення особистості до системи громадських зв'язків, суспільно-трудової діяльності. Науковці А. Вербицький, Н. Колізєєва,В.Брудний, В. Лісовський вивчали особливості адаптації студентів вищих і середніх спеціальних навчальних закладів. Водночас аналіз літератури засвідчує недостатність уваги науковців саме до проблеми розроблення педагогічних моделей адаптації, визначення іiі основних чинників, оскільки сучасні вимоги до навчально-виховного процесу 
потребують посилення педагогічних досліджень у цій сфері задля розроблення ефективних практичних методик щодо адаптації студентів [1].

Мета статті - проаналізувати процес адаптації студентівпершокурсників до умов навчання у ВНЗ.

Виклад основного матеріалу. Аналіз джерельної бази засвідчив, що проблема адаптації, з одного боку, не $\epsilon$ абсолютно новою, а 3 іншого, залишається постійною проблемою. Термін «адаптація» використовується в різних галузях наукових знань, однак вченими ще не вироблено єдиної думки щодо його змісту. Так, одні науковці вважають адаптацію процесом, результатом «пристосування», а інші «взаємодією» людини 3 людиною (певним колективом, групою), або «взаємодією» людини і середовища [3]. Зокрема, В. Слободчиков [4, с. 71] стверджує, що адаптація до навчання у BН3 є складним багатоаспектним включенням студентів у нову систему вимог і контролю, новий колектив, соціальне середовище. Науковці М. Вітковська та І. Троцук виокремлюють соціальну та біологічну адаптацію. На їхню думку, соціальна адаптація - це пристосування індивіда до групи, всього студентського колективу; прийняття нормативно-правових вимог, приписів, норм моралі та культури впродовж перебування у ВНЗ; адаптація до проживання у гуртожитку. Щодо біологічної адаптації, то це адаптація організму до нових умов (кліматичних, побутових, санітарних), режиму праці й сну, фізичних та нервових навантажень; режим і якість харчування [2, с.2]. Ф. Хайруллін розглядає адаптацію як звикання, пристосування особистості до нового оточення. Автор виокремлює два види адаптаџіï залежно від характеру ставлення особистості до умов і змісту конкретної діяльності [5, с. 155]:

- творча адаптація виявляється у повному пристосуванні до навчального процесу (здобуття глибоких i міцних знань, формування творчого мислення і навичок майбутнього фахівця, загальна активність у пізнавальній діяльності);

- формальна адаптація - пристосування не для успішного оволодіння знаннями, а для доведення справи до кінця - одержання диплома.

Пошук шляхів успішної адаптації до соціальних умов та нової діяльності $\epsilon$ нагальною проблемою для студентів, особливо на перших етапах навчання.

Саме цій проблематиці було присвячено проведене дослідження, оскільки проблеми адаптації відчувають майже всі студенти в різному ступені. Репрезентативна вибірка становила 435 чоловік, 61\% - жін., 34\% чол. віком від 14 до18 років, родом з села $-47 \%$, міста $-48 \%$. Перш за все, цікаво було дізнатися чи звикли недавні школярі до студентського життя. Виявилося, що 87\% опитаних увійшли в роль студента. Як правило, студентське життя - це і перший досвід навчання. Цікавим є факт, що 53-м\% респондентів важко звикнути до нової системи навчально-виховного процесу, 32\% -м - до нової системи оцінювання і тільки 3\% студентів було важко увійти в новий колектив. Щодо питання «Наскільки часто Вам 
надають допомогу?», то 50\% таку допомогу надають викладачі, 15\% куратори, $17 \%$ - інші люди і тільки 7\% - члени студентської ради. Щодо змісту цих порад, то найбільше студентів цікавить: «де здобувати інформацію»(24\%), «як користуватися літературою» та «як займатися НДР»(19\%), як ефективно конспектувати лекції (15\%»), «як самостійно опрацьовувати текст» $(10 \%)$, «як раціонально розподіляти час» $(8 \%)$, «як працювати над конспектом».

Відносно сподівань студентів першокурсників щодо рівня викладання навчальних дисциплін, то переважна частина опитаних дала позитивну відповідь (55\%), варіант - так, з окремих дисциплін - обрали 18\%, варіант не зовсім - 8\%. Серед дисциплін, які задовольняють запити студентів названі $75 \%$, не дуже задовольняють $28 \%$, взагалі не задовольняють - $4 \%$ навчальних дисциплін.

Проте студентське життя - це не тільки навчання, а й спілкування 3 друзями одногрупниками, громадське життя, проведення вільного часу. Наскільки студенти змогли реалізувати себе в цьому? Зокрема, «викладачі 3 розумінням i повагою сприймають мене» - стверджує 62\% опитаних, «досить адекватно» - 30\% і тільки 3\% не отримують розуміння, а ще $2 \%$ справедливого ставлення. У молодших спеціалістів ці показники значно вище, а саме: «викладачі та одногрупники сприймають 3 розумінням» - 58\%, «досить адекватно» - 27\%, «не розуміють» - 4\%, несправедливе ставлення $5 \%$. Хотілось сподіватись, що і ця частина студентів зможе знайти спільну мову зі своїми одногрупниками та викладачами. Тим більше, що все таки понад 70\% опитаних вважає, що у них в групі проводяться цікаві заходи, події. Їхнім ініціатором у бакалаврів є куратор - констатує 45\% респондентів, актив групи - 37\%, староста - 25\%, університет - 16\%. У молодших спеціалістів куратор більш ініціативний (53\%), актив групи та академія становлять приблизно однакові показники (37\%) і (17\%), староста - $20 \%$.

Щодо участі у житті університету, то, на жаль, 3-поміж бакалаврів лише 28\% бере участь у спортивних секціях, у студентському самоврядуванні 19\%, у художній самодіяльності - 11\%, профспілковій організації - 7\%, в інших секціях зайнято 20\% опитаних. Щодо молодших спеціалістів, то вони активніші - 23\% у студентському самоврядуванні, по 19\% спортивних секціях та художній самодіяльності, 4\% - у профспілковій організації та 17\% в інших. На питання «Від кого Ви дізнаєтеся про події (життя) в університеті» 64\% респондентів (на базі 11 класів) відповіли, що від старости, 54\% - куратора, 12\% - депутата Студентського парламенту, а до молодших спеціалістів інформацію доносить куратор (65\%), староста (59\%) i, на жаль, лише теж 10\% - депутат Студентського парламенту. Хотілося б сподіватися, що Студентський парламент все таки активізує свою діяльність.

Слід зазначити, що на запитання «Чи бувають у Вас конфлікти» тільки у 2\% вони можуть виникати інколи, а в $1 \%$ - часто - 3 усіма (одногрупниками, викладачами, студентами). Але, незважаючи на це, згуртованою свою групу вважають лише 76\% першокурсників, поділеною на 
мікрогрупи - 13\%, «у нас кожний сам за себе» - 5\% на базі 11 класів. Щодо молодших спеціалістів - то згуртованою свою групу вважають 65\%, поділеною на мікрогрупи - 18\% і тільки 4\% - кожний сам за себе.

На питання «Кому Ви довіряєте розв'язання проблемних ситуацій?» $49 \%$ опитаних відповіли куратору, 40\% - старості, 18 - іншим людям і лише $1 \%$ членам студентського парламенту. 3-поміж молодших спеціалістів 3 куратором поділилися своїми проблемами $-65 \%$, старостою - $29 \%$, іншими людьми $-16 \%$, і членами студентського парламенту - $2 \%$. Отже, отримані результати свідчать про активну діяльність куратора на ФПМС, але, на жаль, відсутність такої у членів студентського парламенту взагалі. Цікавими виявилися питання «Хто для Вас куратор». Зокрема, 48\% відповіли помічник, $37 \%$ - інформатор, $34 \%$ - людина, яка сприяє моєму розвитку, $28 \%$ - друг, 23\% - активний учасник студентського життя і для 5\% опитаних наявність куратора не має ніякого значення. Щодо частоти зустрічей, то щодня з куратором спілкуються $36 \%$, раз на тиждень $-23 \%, 2$ р. в тиждень $24 \%$, раз в місяць $-8 \%$, тільки коли виникають питання - $8 \%$ опитаних. Зрозуміло, що спілкування двічі-тричі на тиждень - це замало. Легкість спілкування свідчить про комунікабельність студентів, авторитет професорсько-викладацького складу та кураторів зокрема.

Учитися бути особистістю - одна 3 найважчих наук, оскільки вона пов'язана 3 удосконаленням характеру, зі здібністю діяти автономно, виявляючи самостійність суджень і високу відповідальність за свої дії та вчинки. Виховний вплив на молоду людину здійснюють рідні, друзі, однолітки, ЗМІ тощо. Проте вирішальне значення мають учителі, викладачі, які допомагають оволодіти знаннями, обраною професією. Особливої уваги потребує запитання «Якщо б у Вас була можливість повернути час назад, вступили б Ви знову в академію?». 72\% молодших спеціалістів і $81 \%$ студентів на базі 11 класів, знову вступили б до нас навчатися, а 12 i відповідно 14\% відповіли «ні».

Висновок. Отже, проведене дослідження показало, що адаптація студентів в умовах вищого навчального закладу є складним, багатоаспектним i динамічним процесом. Аналіз отриманих результатів свідчить про те, що у студентів-першокурсників соціальна адаптація пройшла досить швидко i майже $90 \%$ опитаних увійшли в роль студента, пристосувалися до групи, студентського колективу, прийняли правила перебування у ВНЗ тощо. Біологічна адаптація проходила важче, оскільки майже $50 \%$ респондентів були родом із села, а, отже, їм доводилося жити самостійно, без батьків, родичів. Але, з іншого боку, ці діти швидше адаптувалися до дорослого життя, режиму праці, харчування й сну, фізичних та нервових навантажень тощо, ніж студенти з міста, які проживали «під крилом у батьків».

Аналіз процесу адаптації залежно від характеру ставлення особистості до умов і змісту конкретної діяльності свідчить, що у студентів-першокурсників ВНЗ наявна як формальна адаптація, тобто пристосування задля отримання диплома, так і творча адаптація. Але, на жаль, студентам досить важко 
пристосуватися до нових навчально-виховного процесу, системи оцінювання, які суттєво відрізняються від умов загальноосвітньої школи. Слід зазначити, що від успішності процесу адаптації першокурсників багато в чому залежать подальші професійна кар'єра й особистісний розвиток майбутнього фахівця 3 вищою освітою. Удосконаленню навчального процесу, самореалізації особистості студентів, формуванню в них організаторських навичок, лідерських якостей, відповідальності за результат своєї праці, забезпеченню виховання духовності та культури, зростанню соціальної активності у молоді повинні сприяти також і органи студентського самоврядування, старостат. Результати дослідження засвідчили слабку організацію діяльності цієї ланки ( $20 \%)$. Сподіваємося, що у майбутньому вони братимуть активнішу участь у житті навчального закладу, співпрацювати $з$ органами студентського самоврядування інших ВНЗ міста, ВН3 інших країн, міжнародними студентськими організаціями та їх об'єднаннями, що сприятиме удосконаленню навчальної, науково-дослідної та виховної роботи зі студентами; творчому, інтелектуальному, духовному та фізичному розвитку студентів-першокурсників, самовизначенню їх особистості, відродженню національних традицій історії та культури українського народу, сімейних традицій тощо.

\section{Література}

1. Алексеєва Т. В. Психологічні чинники та виявлення процесу адаптації студентів до навчання у ВНЗ : автореф. дис. канд. психол. наук: 19.00.01 /Т. В. Алексеєва. - К. : Київ. нац. ун-т ім. Т.Шевченка, 2004. - 20 с.

2. Витковская М. И. Адаптация иностранных студентов к условиям жизни и учебы в России (на примере РУДН) / М. И. Витковская, И. В. Троцук // Вестник РУДН. Серия «Социология». - 2004. - № 6-7. [Электроный ресурс] / Режим доступа: http://articles.excelion. ru/science/filosofy/22017026.html.

3. Левківська Г. П. Адаптація першокурсників в умовах вищого навчального закладу освіти : [навч. посіб.] / Г. П. Левківська, В. С. Сорочинська, В. С. Штифурак. - К., 2001. $-128 \mathrm{c}$.

4. Слободчиков И. М. Переживание одиночества в контексте проблем психологической адаптации студентов психолого-педагогических вузов / И. М. Слободчиков // Психол. наука и образование. - 2005. - № 4. - С. 71-77.

5. Хайруллин Р. 3. Культура межнационального общения учащихся как объект междисциплинарного исследования / Р. З. Хайруллин // Толерантность и проблема идентичности. Материалы международной научно-практической конференции: [ежегодник Российского психологического общества]. - Т.9. - Ижевск, 2002. - Вып.4. C. $154-160$.

6. Шапар В. Б. Психологічний тлумачний словник / В. Б. Шапар. - Х., 2004. - 640 с.

Стаття надійшла до редакції 17.05.2012 p. 